\title{
HUMAN IMPACTS ON MACROPHYTE DIVERSITY, WATER QUALITY AND SOME SOIL PROPERTIES IN THE MADIKANE AND DUFUYA WETLANDS OF LOWER GWERU, ZIMBABWE
}

\author{
Dube, T.* - Chitiga, M. \\ Midlands State University \\ Department of Biological Sciences, P.O. Bag 9055, Gweru, Zimbabwe \\ (phone: $+263-54-260568$; fax: $+263-54-260311$ ) \\ *Corresponding author \\ e-mail:tdube@msu.ac.zw \\ (Received $10^{\text {th }}$ August 2010 ; accepted $28^{\text {th }}$ January 2011 )
}

\begin{abstract}
This study investigated how the exploitation of wetlands, locally known as dambos, changes their vegetation composition, soil properties and how that in-turn affects the water quality. We therefore compared diversity and soil conditions between a protected (Madikane) and exploited (Dufuya) dambo impacted by communal agriculture and grazing in Lower Gweru, Zimbabwe. Species diversity was higher in Madikane $\left(\mathrm{H}^{\prime}=2.52\right)$ than Dufuya $\left(\mathrm{H}^{\prime}=2.14\right)$. Species that were present in Madikane indicated a permanent or semi-permanent wetness compared to species tolerant to arid conditions, reflecting disturbance in Dufuya. Dambo utilization also indicated a change in dominance from perennials to annuals and an increase in exotic species. There was no significant difference in the physical structure of the soil between the rather pristine and exploited sites (\% clay and $\%$ silt, $\mathrm{p}>0.05)$. A significant difference was recorded in the chemical properties of the soil $(\mathrm{pH}$, phosphorus, nitrate- $\mathrm{N}$, ammonium- $\mathrm{N}$ and organic carbon content). Water quality was good in the protected dambo than the exploited dambo as indicated by the differences in calcium ions and conductivity. The protection of wetlands is shown to be important in conserving biological diversity.
\end{abstract}

Keywords: dambo, species diversity, agriculture, soil condition

\section{Introduction}

African wetlands are an important resource base and are actively utilised by rural communities for socio-economic activities (Kirstern, 2005). The good water quality in wetlands allows a rich assemblage of plant and animal life to develop, hence they are a rich source of macrophyte biodiversity (Mitsch and Gosselink, 1993). The rapid loss of species from wetlands has led to a decline in productivity, nutrient retention and resistance to invasion by introduced plant species (Tilman, 1996; Loreau, 2000; Naeem et al., 2000). Despite their importance, wetlands are being continuously modified or reclaimed for agricultural purposes.

In Zimbabwe, wetlands are locally known as dambos (Whitlow, 1984; 1985b). They cover about 1.28 million ha or $3.6 \%$ of the country's land area and $84 \%$ of them are located towards the north of the country on the undulating highveld plateau above $1200 \mathrm{~m}$, where the mean annual rainfall is above $800 \mathrm{~mm}$. The dispersed distribution of dambos has made them accessible to a high proportion of the rural population (Dambo Research Unit, 1987). The use of dambos as pasture and cultivation area has increased due to the growing rural population and economic pressures (Whitlow, 1983). As a result, dambo cultivation has become a well-established tradition amongst rural farmers in Zimbabwe such that their gardens provide a regular supply of crops (Whitlow, 1983; Acres, 1985), which is especially important during drought years. 
The ecological value of dambos in Zimbabwe has been taken for granted because of incorrect public perceptions, poor legislation and conservation strategies that are not backed by adequate scientific research (Matiza, 1994). This makes it difficult to plan for dambo conservation and to integrate conservation and development goals at a local level. Much of what is known about local dambos relates to their agricultural uses (Whitlow, 1985a). There is a need to continue research on dambos and their biodiversity, especially in view of the growing level of human impacts that are contributing to their destruction. This study investigated how the exploitation of dambos may change their vegetation composition, soil properties and how that will in-turn affect the surface water quality by comparing a dambo disturbed through agriculture with a relatively undisturbed one.

\section{Materials and Methods}

\section{Study Area}

Madikane and Dufuya dambos are located $90 \mathrm{~km}$ west of Gweru in the Zimbabwean Midlands (Figure 1). The area is overlaid by Kalahari Sands with gentle relief that has allowed the extensive development of dambos. The soil in the wetter parts of the dambos tends to be waterlogged and rich in organic matter and they support areas of grassland interspersed amongst the woodland. The average rainfall of the area is 650 $\mathrm{mm}$ as it is throughout Zimbabwe. Rainfall is strongly seasonal with one rainy season lasting from November to March.

The Dufuya system is located at $19^{\circ} 16^{\prime} \mathrm{S}, 2^{\circ} 19^{\prime} \mathrm{E}$ at an altitude of $1274 \mathrm{~m}$ next to Dufuya Primary School along the Sogwala road and drains into the Somkamba stream, a tributary of the Vungu River. The dambo area is 63.3 ha in extent, 28.2 ha is cultivated with about 212 gardens (mean area $=0.127 \mathrm{ha}$ ). Water drains into the dambo from a large spring, which is covered by a dense growth of vegetation. An intermittent stream meanders southwards from the spring creating a perennially damp marshy strip that bisects the system with two similar sets of gardens flanking either side of the open marshy strip. The gardens near the central drainage area are wetter than those towards the edge of the dambo that are drier and have sandier soils.

Madikane dambo is located at $19^{\circ} 14^{\prime} \mathrm{S}, 29^{\circ} 15^{\prime} \mathrm{E}$ at an altitude of $1256 \mathrm{~m}$ and is about $15 \mathrm{~km}$ from the Dufuya dambo and it also drains into the Somkamba stream. It is protected by the Environmental Management Agency as well as by the local villagers to whom the area is sacred and therefore cultivation is not permitted. Water drains from a spring into the dambo and meanders south into Somkamba stream. 


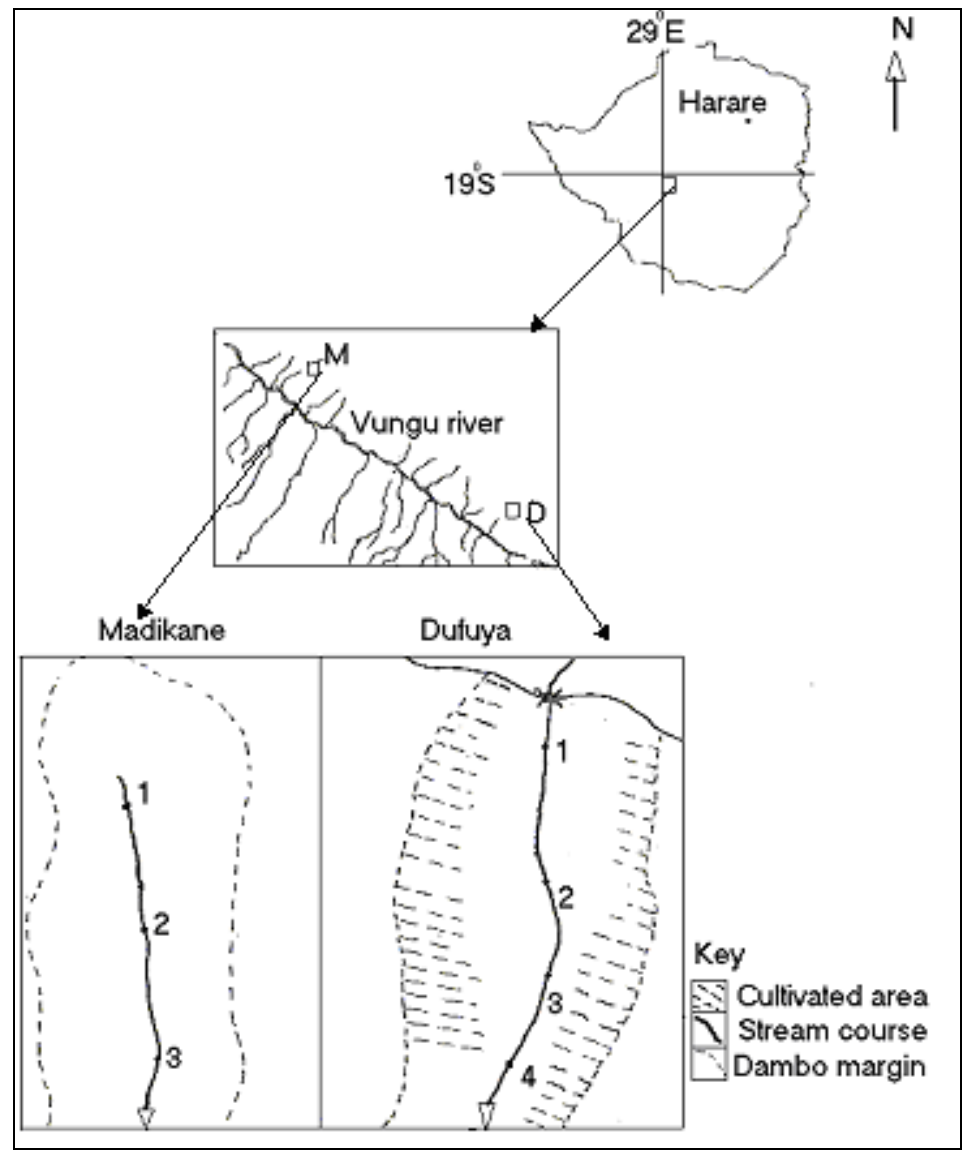

Figure 1. The location of the study sites showing the spatial relationship of the dambos Madikane (M) and Dufuya (D) and sampling stations

\section{Diversity assessment}

Plots that covered the outer and the central dambo zones were selected for the sampling of macrophytes. The two zones in the wetland were identified according to the amount of standing water in them. The outer area was marshy whereas the central zone was swampy with open water zones. Plants were sampled by means of quadrats. Line transects of $80 \mathrm{~m}$ were laid at $15 \mathrm{~m}$ intervals in Madikane dambo and at $50 \mathrm{~m}$ intervals in Dufuya. This was done so as to have an equal number of quadrats from both dambos. Plants were sampled along each transect by laying a $25 \mathrm{~cm} \times 25 \mathrm{~cm}$ quadrat at $10 \mathrm{~m}$ intervals and recording the species composition, species abundance, and percentage cover in each quadrat. The plants encountered were identified with the help of the national herbarium using standard identification keys for the flora of Southern Africa (Bennet, 1980; Chapano, 2002).

\section{Soil characteristics}

Soil sampling was done in November 2004. Soil samples were taken with a soil auger measuring $5 \mathrm{~cm}$ in diameter and $20 \mathrm{~cm}$ in depth. Fifteen surface $(0-20 \mathrm{~cm})$ and five subsurface $(20-100 \mathrm{~cm})$ cores were taken from each dambo. The samples were placed into self-sealing plastic bags and stored in a cooler until laboratory analysis. The $\mathrm{pH}$ of the soil was determined with a Philips digital $\mathrm{pH}$ meter (PW 9419) in a 2:1 water to soil ratio. The soil samples intended for the determination of total organic carbon 
were air dried, homogenized with a pestle and mortar and passed through a $2 \mathrm{~mm}$ sieve. The samples were then oxidized with a mixture of $1 \mathrm{~N}$ potassium dichromate $\left(\mathrm{K}_{2} \mathrm{Cr}_{2} \mathrm{O}_{7}\right)$ and concentrated sulphuric acid $\left(\mathrm{H}_{2} \mathrm{SO}_{4}\right)$ and the soil digest was titrated against a $0.2 \mathrm{M}$ ferrous ammonium sulphate solution (Schnitzer, 1982).

Exchangeable ammonium was determined from undried samples by extracting with $0.5 \mathrm{M}$ solution $\mathrm{K}_{2} \mathrm{SO}_{4}$, and filtration through Whatman 42 filter paper followed by colorimetric estimation. A similar procedure was used for the determination of nitratenitrogen except that filtration was followed by cadmium reduction (Keeney and Nelson, 1982). Total nitrogen and total phosphorus were determined by digestion of soil at $110{ }^{\circ} \mathrm{C}$ for 1 hour in concentrated sulphuric acid followed by colorimetric estimation. Plant available phosphate was determined by the Bray method (Bray and Kurtz, 1945) in which $2.5 \mathrm{~g}$ of air dried soil was extracted with Bray P2 solution $\left(0.03 \mathrm{~N} \mathrm{NH}_{4} \mathrm{~F}\right.$ and $0.1 \mathrm{~N} \mathrm{HCl}$ ) followed by colorimetric estimation. Particle size distribution was determined by the hydrometer method in which $50 \mathrm{~g}$ of air dried soil was saturated with distilled water. The soil suspension was mixed with $300 \mathrm{ml}$ tap water in a graduated cylinder where hydrometer readings and the temperature of the suspension were taken after 40 seconds and after 2 hours (Gee and Bouder, 1986).

\section{Water quality}

Water samples were taken in November 2004, January 2005 and March 2005 from 5 sampling points in Dufuya dambo and 3 sampling points in Madikane dambo (Figure 1). At each sampling point, the following physical and chemical variables were measured with a Horiba UU 23 multi-probe meter (Horiba Ltd, Japan): temperature $\left({ }^{\circ} \mathrm{C}\right)$, dissolved oxygen $\left(\mathrm{mg} 1^{-1}\right)$, turbidity (NTU), conductivity $\left(\mu \mathrm{S} \mathrm{cm}^{-1}\right)$ chloride, calcium and $\mathrm{pH}$. Duplicate samples were taken at a depth of $10 \mathrm{~cm}$ with a plastic water sampler and placed in 1L polyethylene bottles and stored in an icebox at $4^{\circ} \mathrm{C}$. The samples were transferred to the laboratory for the determination of total nitrogen, total phosphorus and ammonium nitrogen. The samples were analysed within 24 hours using HACH ER/ 04 kits. Total phosphorus was determined by the acid persulfate digestion method which measured soluble reduced phosphate in the digested solution (method 8190). Total nitrogen was determined by alkaline persulfate digestion (method 10071) while ammonia was determined by the salicylate method (method 10023).

\section{Data analysis}

The plant data collected were used to compute community indices such as Sorensen's similarity index, Shannon-Wiener's diversity index, and Shannon index of evenness so as to evaluate the differences in the plant diversity of the two dambos (Sorensen, 1948; Shannon and Wienner, 1963). Cluster analysis (Minitab 13.0) was used to compare the two dambos in terms of their species composition by grouping quadrats with more similar species into the same clusters. Cluster analysis is an agglomerative method that starts with small groups of few samples, and progressively groups them into larger homogeneous units until the whole data set is sampled (Everitt, 1993). ANOVA was used to test for the significant differences in the soil physical and chemical parameters and water variables between the dambos (Minitab, 1995). 


\section{Results}

\section{Plant diversity}

A total of 51 species were recorded in the two dambos (Table 1). Madikane had 39 species belonging to 17 families, while Dufuya had 29 species belonging to 10 families. Thirty one percent of the species occurred in both dambos. Grasses made up $18 \%$ of the total in Madikane and 14\% in Dufuya and only one tree species, Ficus thonningii, was recorded (in Madikane). Exotic species were present in both dambos but they were more numerous in Dufuya with five species, amounting to $17 \%$ of the total, compared to Madikane with only three species, or $5 \%$ of the total.

Species diversity was higher in Madikane $\left(\mathrm{H}^{\prime}=2.52\right)$ than in Dufuya $\left(\mathrm{H}^{\prime}=2.14\right)$. The dominant species in Madikane were Thelypteris confluens, Kyllinga erecta, Carex cognata, Cyperus rotundus, and Cyperus articulatus, which made up 75\% of the total. In Dufuya, the dominant species were Fimbristylis dichotoma, Kyllinga erecta and the unidentified Asteraceae Species A, which made up $70 \%$ of the total. There was a significant difference in species composition between Madikane and Dufuya (t-test, $\mathrm{p}<0.05)$.

The central region of Madikane was dominated by Thelypteris confluens ( $15.87 \%)$, Phragmites australis $(15.84 \%)$ and the Cyperus articulatus $(36.08 \%)$ while the central region of Dufuya was dominated by Kyllinga erecta (29.79 \%), Fimbristylis dichotoma $(22.4 \%)$ and the Asterceae Species A (23.02\%). The Sorensen similarity index for the central regions was $11 \%$. The outer region of Madikane was dominated by Cyperus rotundus, Kyllinga erecta and Thelypteris confluens while the comparable regions of Dufuya were characterized by species of disturbed ground, Cleome gynandra (2\%), Bidens pilosa (1\%), Amaranthus hybridus (4\%) and Cynodon dactylon (7\%) a species that occurs widely in overgrazed areas.

A cluster analysis of species composition separated the dambos into three distinct clusters with Madikane and Dufuya being distinctively separated (Figure 2). The outer zone of Madikane was widely separated from the central zone and was rather closer to the Dufuya cluster. This was a result of 22 species that were present in Madikane but absent in Dufuya, 12 species present in Dufuya but absent in Madikane and 10 species that were common to Dufuya and the outer region of Madikane. The central region of Madikane was separated from the rest of the regions because it was dominated by Thelypteris confluens and Phragmites australis suggesting a wet environment in that region. 
Table 1. The mean composition (\% by numbers) of macrophytes in two different zones of the two dambos $(O=$ outer, $C=$ central, $M=$ Madikane, $D=$ Dufuya). Species marked * are exotics and † are herbs.

\begin{tabular}{|c|c|c|c|c|c|}
\hline Family & $\begin{array}{r}\text { Species } \\
\end{array}$ & MO & MC & DO & DC \\
\hline Acanthaceae & Hypoestes forskalei $\dagger$ & & & 0.44 & 0.05 \\
\hline Amaranthaceae & Amaranthus hybridus* ${ }^{*}$ & & & 3.51 & \\
\hline Anacardiaceae & Pyroides pyroides & & 0.11 & & \\
\hline Apiaceae & Hydrocotyle bonariensis $* \dagger$ & 3.37 & 3.42 & & \\
\hline \multirow[t]{11}{*}{ Asteraceae } & Conyza welwitschii $\uparrow$ & 1.35 & 0.15 & & \\
\hline & Pseudognaphalium album $\dagger$ & 0.03 & & & \\
\hline & Osteospermum monocephalum & 0.38 & & 0.08 & 0.32 \\
\hline & Senecio strictifolius $\uparrow$ & & 0.04 & & \\
\hline & Blumea solidaginoides $\dagger$ & 0.10 & & & \\
\hline & Conyza sumatrensis $* \dagger$ & & & 0.65 & \\
\hline & Lactuca indica $\uparrow$ & & & 0.13 & 0.11 \\
\hline & Bidens pilosa $\dagger$ & & & 1.30 & \\
\hline & Otomeria elatior $\dagger$ & & & 4.75 & \\
\hline & Species A & 10.73 & 1.75 & 19.36 & 23.02 \\
\hline & Species B & 0.75 & & & \\
\hline Capparidaceae & Cleome gynandra $\dagger$ & & & 1.19 & \\
\hline \multirow[t]{7}{*}{ Cyperaceae } & Cyperus rotundus & 19.34 & & 0.43 & \\
\hline & Kyllinga alba & 4.76 & & 4.54 & 2.95 \\
\hline & Fuirena pubescens & 0.02 & & & \\
\hline & Kyllinga erecta & 14.08 & 2.33 & 35.10 & 29.79 \\
\hline & Carex cognate & 7.63 & 12.89 & 0.08 & 3.46 \\
\hline & Fimbristylis dichotoma & 0.10 & & 13.65 & 22.40 \\
\hline & Cyperus articulates & 8.82 & 36.08 & 0.15 & 0 \\
\hline Fabaceae & Tephrosia spp. $\dagger$ & 0.02 & & & \\
\hline Fumariaceae & Chironia palustris $\dagger$ & 0.03 & & & \\
\hline Malvaceae & Sida rhombifolia $\dagger$ & & 0.04 & & \\
\hline Moraceae & Ficus thonningii & & 0.07 & & \\
\hline Musaceae & Musa caventish* & & & & 0.03 \\
\hline \multirow[t]{2}{*}{ Onagraceae } & Epilobium salignum $\dagger$ & 0.10 & & & \\
\hline & Ludwigia stolonifera $\uparrow$ & 0.13 & & & \\
\hline Orobanchaceae & Cycnium tubulososum $\dagger$ & 0.48 & 0.55 & 0.79 & 3.17 \\
\hline \multirow[t]{14}{*}{ Poaceae } & Panicum repens & 5.37 & & 1.23 & 7.76 \\
\hline & Cynodon dactylon & 1.87 & & 7.34 & 0.99 \\
\hline & Eragrostis inamoena & 0.38 & & & \\
\hline & Paspalum scrobiculatum & 0.25 & & & 1.29 \\
\hline & Andropogon eucomus & 0.02 & & 0.32 & 0.35 \\
\hline & Sporobolus pyramidalis & 0.01 & & 0.87 & \\
\hline & Eragrostis cylindriflora & & & 0.08 & \\
\hline & Eriochloa macclounii $\dagger$ & & & 0.08 & \\
\hline & Eragrostis heteromera & & & 2.60 & \\
\hline & Paspalum urvillei* & & & 0.43 & 3.14 \\
\hline & Phragmites australis & 1.47 & 15.84 & & \\
\hline & Species C & & 4.88 & & \\
\hline & Species D & 4.27 & 3.39 & & \\
\hline & Species E & 0.15 & & 0.22 & 0.24 \\
\hline Rosaceae & Potentilla spp. $* \dagger$ & & 0.07 & & \\
\hline Rubiaceae & Richardia scabra $\dagger$ & & 0.22 & & \\
\hline Solanaceae & Physalis peruviana $\dagger$ & & 0.11 & & \\
\hline Thelypteridaceae & Thelypteris confluens $\dagger$ & 13.06 & 15.87 & & \\
\hline Tyhaceae & Typha capensis $\dagger$ & 0.92 & 2.22 & 0.65 & 0.91 \\
\hline Verbenaceae & Lantana camara* & 0.01 & & 0.02 & \\
\hline Species diversity (H') & & 2.48 & 1.92 & 2.09 & 1.88 \\
\hline$\left(\mathrm{E}_{\mathrm{H}}\right)$ & & 0.72 & 0.65 & 0.63 & 0.66 \\
\hline
\end{tabular}




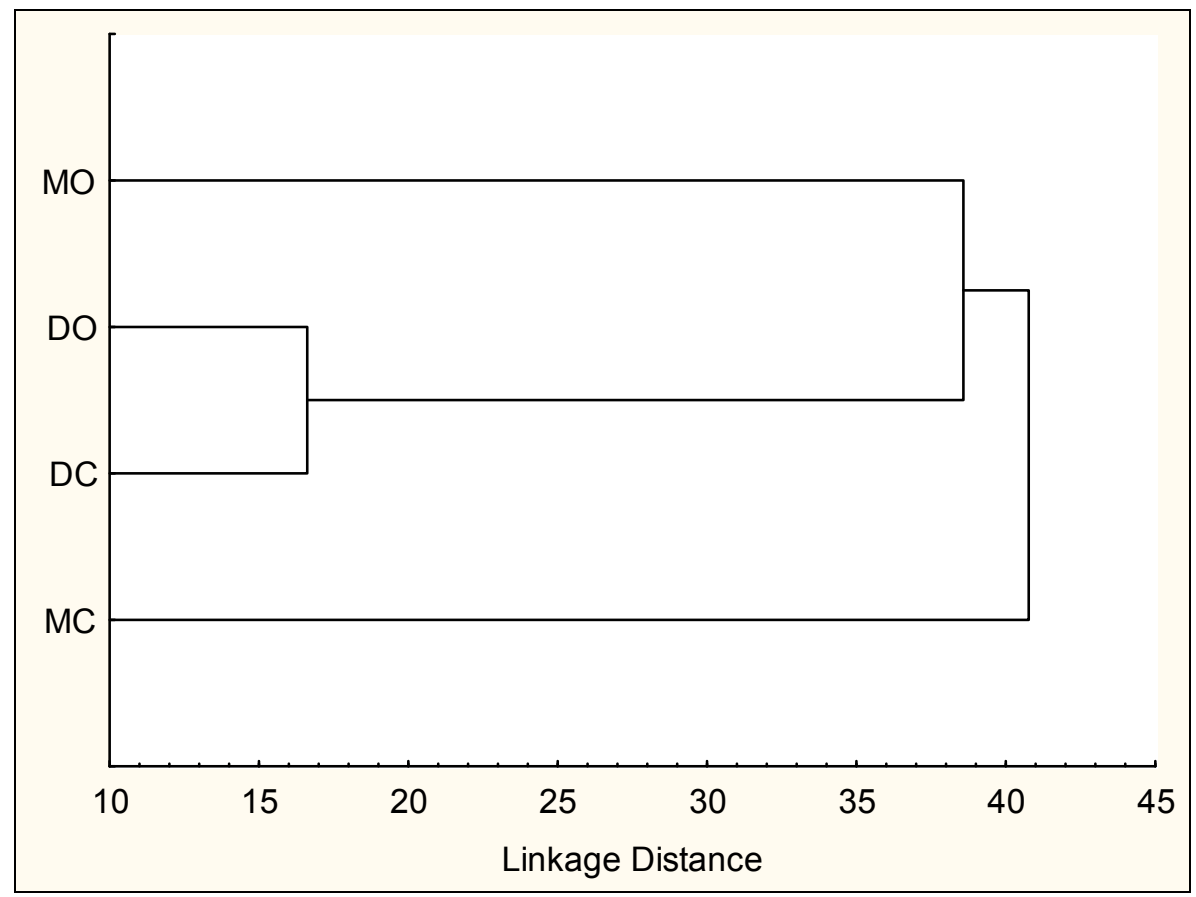

Figure 2. A dendrogram of species composition in the study areas $(O=$ Outer and $C=$ central; $M=$ Madikane and $D=$ Dufuya $)$

\section{Soil Properties}

The concentrations of ammonia, nitrate-nitrogen and total nitrogen in the soil was significantly higher in the surface layers of Madikane than in Dufuya (Figure 3). This was also true for ammonium and total nitrogen in the deeper layers. Nitrate-nitrogen was much higher in the deeper layers of Dufuya. The differences between the two dambos were significant (ANOVA, $\mathrm{p}<0.05$ ) in each case.

The concentration of phosphorus was higher in Dufuya than Madikane (Table 2). Soil $\mathrm{pH}$ was relatively higher in Madikane than Dufuya with a range of $4.98-10.15$ and $5.26-7.86$ respectively. The slight acidity of the soil in some parts of Dufuya and Madikane suggest the release of humic acids from organic matter decomposition. 


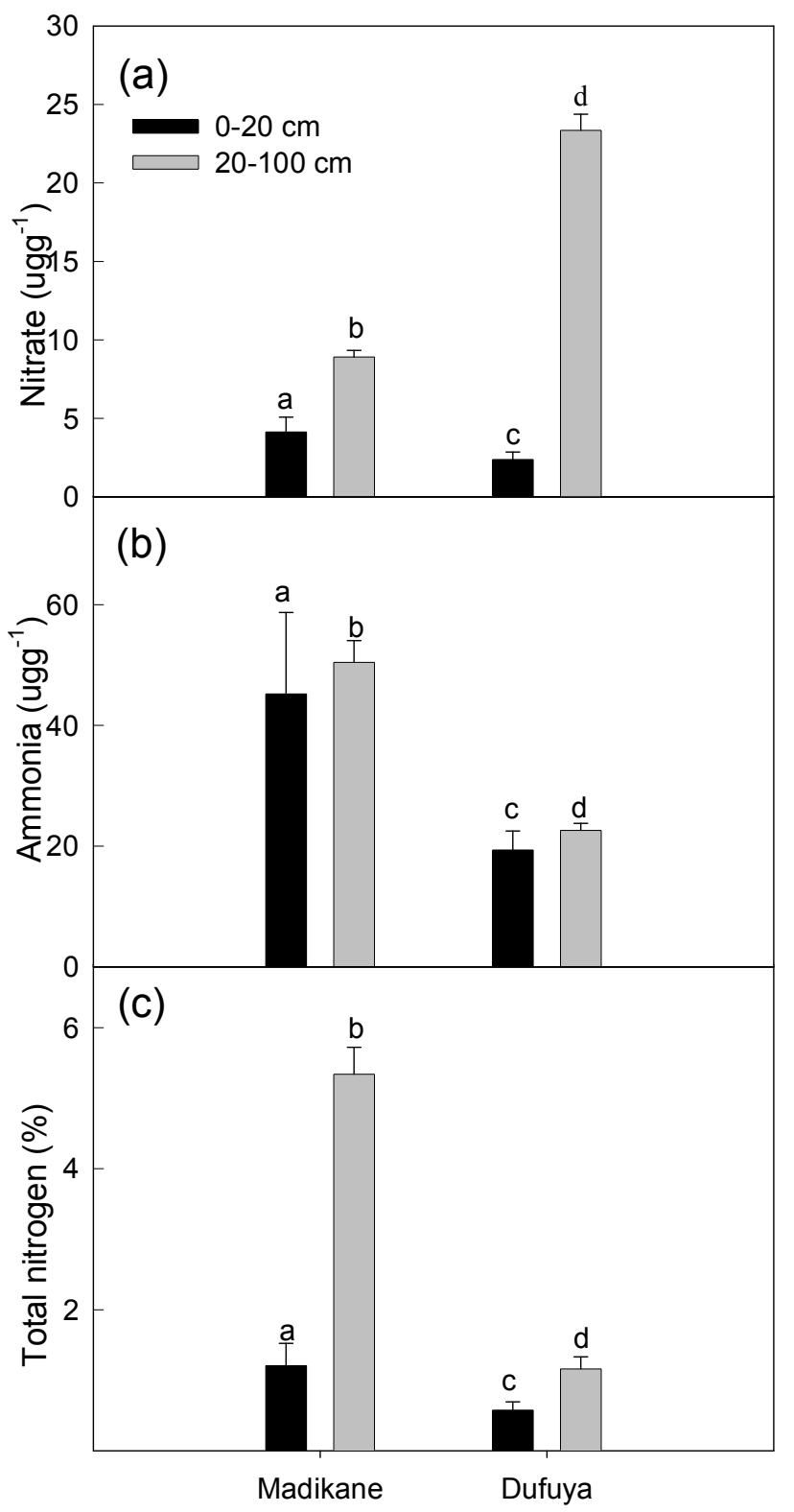

Figure 3. Mean concentrations of (a) nitrate nitrogen ( $\mu \mathrm{g} \mathrm{NO} \mathrm{O}_{3} \mathrm{~g}^{-1}$ soil), (b) ammonium nitrogen $\left(\mu \mathrm{g} \mathrm{NH}{ }_{4}^{+} \mathrm{g}^{-1}\right.$ soil) and (c) total nitrogen (\%), in surface (0-20 cm) and subsurface (20-100 cm) samples. Values presented are means \pm standard deviation. Values with the same superscript are not significantly different $(p>0.05)$

Table 2. Mean concentration of total phosphorus (P), plant available phosphorus $\left(\mathrm{P}_{2} \mathrm{O}_{5}\right)$ and $p H$ in Madikane and Dufuya with significantly different $(p<0.05)$ values highlighted in bold

\begin{tabular}{lcc}
\hline & Madikane & Dufuya \\
\hline $\mathrm{PH}$ & 6.9 & 6.3 \\
$\mathrm{P}(\%)$ & 0.03 & 0.04 \\
$\mathrm{P}_{2} \mathrm{O}_{5}\left(\mu \mathrm{g} \mathrm{g}^{-1}\right)$ & $\mathbf{6 6 . 4 8}$ & $\mathbf{7 9 . 2 5}$ \\
\hline
\end{tabular}


The concentration of organic carbon in both dambos was higher in the central zone than in the outer zone although it was significantly lower in Dufuya (Figure 4). The concentrations in the drier outer zones were much lower than in the central zones and although the differences between the two dambos were relatively small they were still significant. Moisture content in the central and outer zones ranged between $60-90 \%$ and $1-45 \%$ respectively.

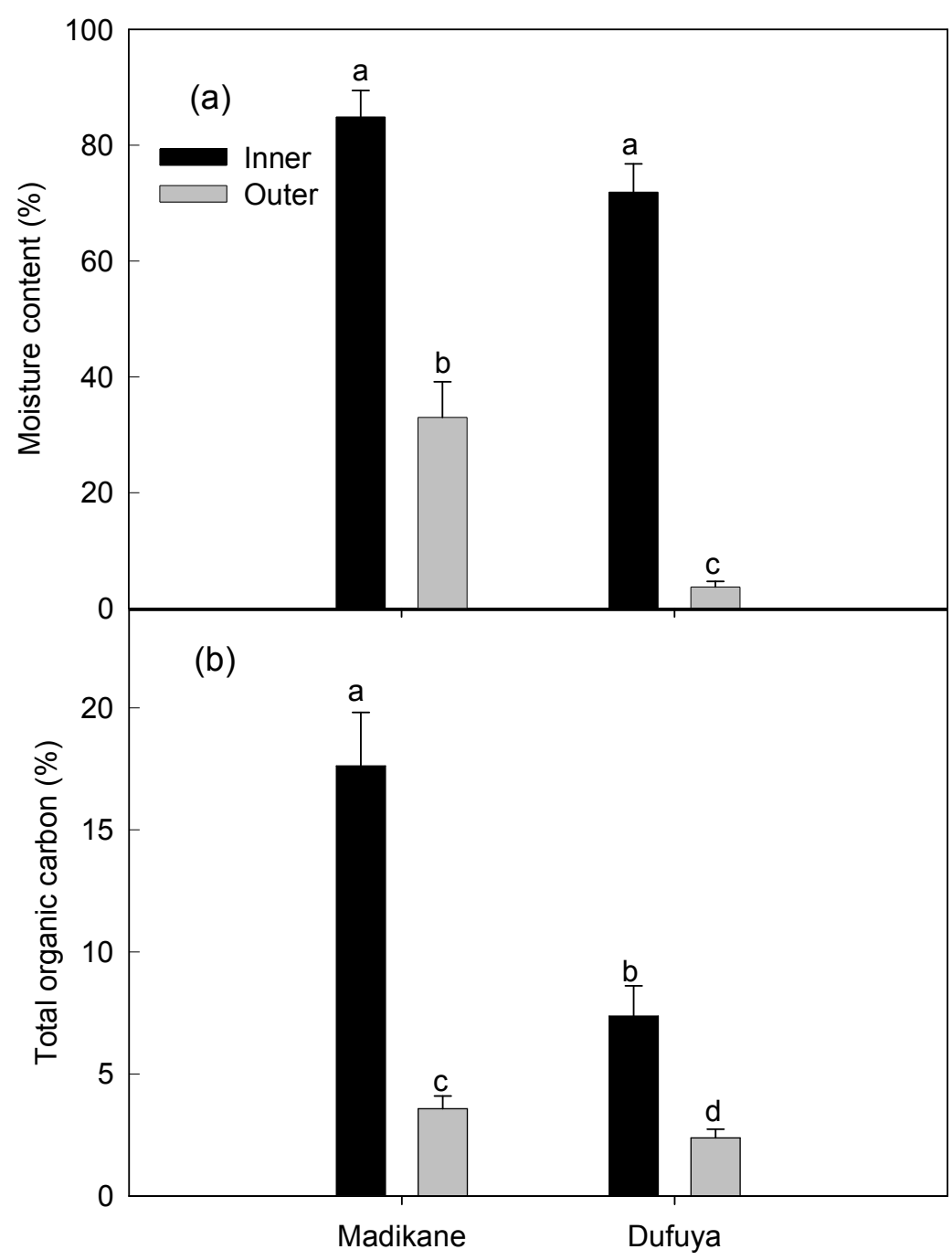

Figure 4. Mean content of (a) moisture (\%) and (b) total organic carbon in the outer and in the central zone of Madikane and Dufuya. Values presented are mean \pm standard deviation. Values with the same superscript are not significantly different (ANOVA: $p>0.05$ )

There was a significant correlation between the amount of total organic carbon and moisture content in Madikane (Pearson correlation, $r=0.74)$ and Dufuya $(r=0.88)$. The amount of total organic carbon significantly increased with the increase in moisture content (Figure 5). The increase in organic carbon with moisture content was more pronounced in Madikane $\left(\mathrm{r}^{2}=0.78\right)$ than Dufuya $\left(\mathrm{r}^{2}=0.54\right)$. 


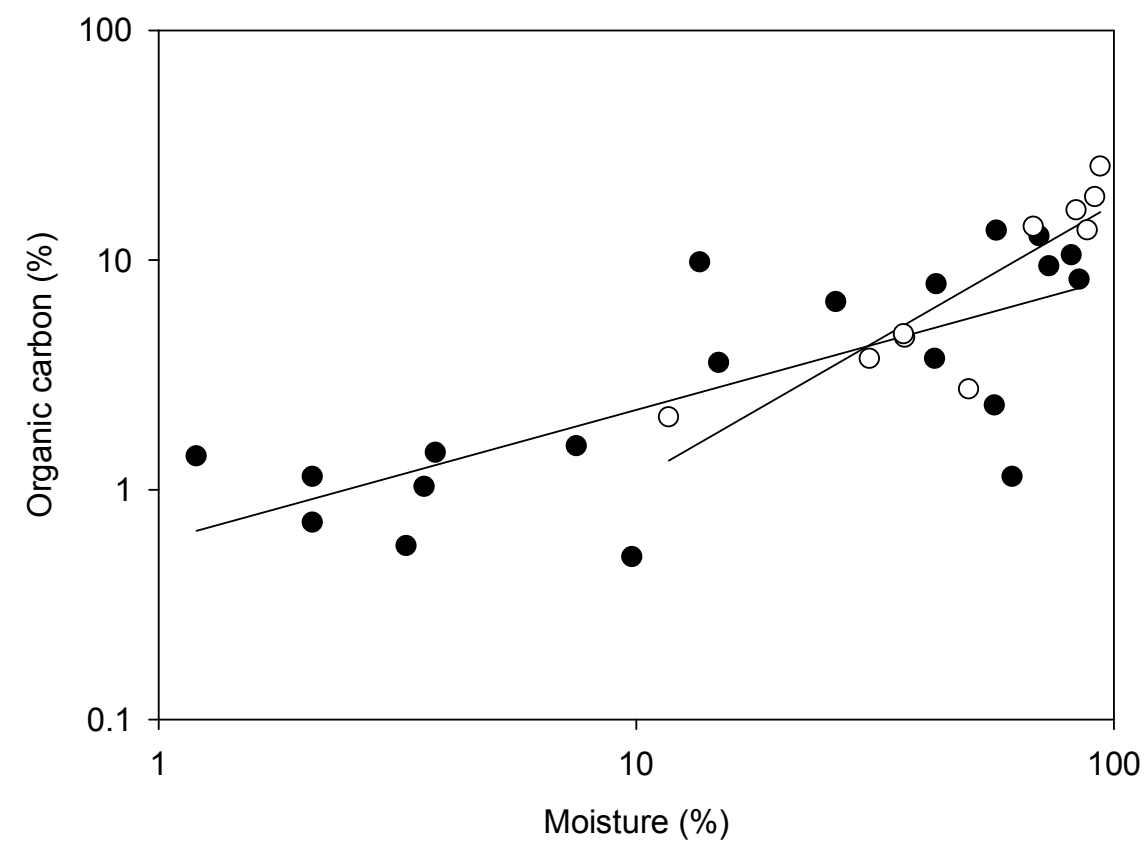

Figure 5. The relationship between moisture content and organic carbon in Dufuya (O) and Madikane (O). Regression lines were fitted as follows: $y=-0.22+0.57 x, r^{2}=0.54$ (Dufuya) and $y=-1.15+1.20 x, r^{2}=0.78$ (Madikane)

The majority of soils sampled in the two dambos were loamy sand or sandy loam with clay content ranging from 3-29\% in Dufuya and 5-19\% in Madikane (Table 3). Clay loam soils were only present in two sites in Dufuya. There were no significant differences detected in particle size composition between the two dambos, $\%$ silt (t-test, $\mathrm{p}>0.05)$ and $\%$ clay $(\mathrm{p}>0.05)$.

Table 3. The physical structure of soil in Madikane and Dufuya. Values presented are means \pm standard deviations. Values with the same superscript are not significantly different (t-test: $p>0.05)$

\begin{tabular}{lccc}
\hline & Sand & Clay & Silt \\
\hline Dufuya & $72.2 \pm 14.75^{\mathrm{a}}$ & $13.0 \pm 7.01^{\mathrm{b}}$ & $14.8 \pm 9.34^{\mathrm{c}}$ \\
Madikane & $77.8 \pm 9.19^{\mathrm{a}}$ & $10.7 \pm 4.33^{\mathrm{b}}$ & $11.5 \pm 6.82^{\mathrm{c}}$ \\
\hline
\end{tabular}

\section{Water quality}

The concentration of total nitrogen was relatively low in both dambos $(1.30 \pm 0.23$ $\mathrm{mg} \mathrm{L}^{-1}$ in Madikane dambo and $1.17 \pm 0.25 \mathrm{mg} \mathrm{L}^{-1}$ in Dufuya) but there was no significant difference between them (ANOVA, $p>0.05$ ). The concentrations of ammonium nitrogen levels ranged from 0.01 to $0.05 \mathrm{mg} \mathrm{L}^{-1}$ in both dambos and the differences between them were also not significant (Table 4). The concentration of phosphorus was significantly higher $(\mathrm{p}<0.05)$ in Dufuya $\left(1.30 \pm 0.26 \mathrm{mg} \mathrm{L}^{-1}\right)$ than in Madikane $\left(0.66 \pm 0.12 \mathrm{mg} \mathrm{L}^{-1}\right)$. Calcium was significantly higher in Dufuya than in 
Madikane but there was no significant difference $(\mathrm{p}>0.05)$ in the concentration of chloride. The $\mathrm{pH}$ of water in Madikane varied from 6.71 to 10.0 while it was nearly neutral in Dufuya (6.70 to 7.07). The conductivity was significantly $(p<0.05)$ higher in Dufuya $\left(287 \pm 36.18 \mu \mathrm{S} \mathrm{cm} \mathrm{cm}^{-1}\right)$ than in Madikane $\left(125 \pm 3.61 \mu \mathrm{S} \mathrm{cm} \mathrm{cm}^{-1}\right)$ but the concentration of dissolved solids was the same in both wetlands with a range of 0.1 to $0.2 \mathrm{~g} \mathrm{~L}^{-1}$. The concentration of dissolved oxygen in Madikane ranged from $4.8-6.3$ $\mathrm{mg} \mathrm{L}^{-1}$ and in Dufuya from $6.6-8.1 \mathrm{mg} \mathrm{L}^{-1}$.

Table 4. Water quality variables of Madikane and Dufuya

\begin{tabular}{lcc}
\hline & Madikane & Dufuya \\
\hline $\mathrm{AN}\left(\mathrm{mg} \mathrm{L}^{-1}\right)$ & $0.05 \pm 0.01$ & $0.03 \pm 0.02$ \\
$\mathrm{TDS}\left(\mathrm{g} \mathrm{L}^{-1}\right)$ & $0.13 \pm 0.05$ & $0.12 \pm 0.03$ \\
$\mathrm{~N}\left(\mathrm{mg} \mathrm{L}^{-1}\right)$ & $1.30 \pm 0.23$ & $1.17 \pm 0.25$ \\
$\mathrm{P}\left(\mathrm{mg} \mathrm{L}^{-1}\right)$ & $0.66 \pm 0.12$ & $1.30 \pm 0.26$ \\
$\mathrm{Ca}\left(\mu \mathrm{g} \mathrm{L}^{-1}\right)$ & $1.21 \pm 0.42$ & $2.23 \pm 0.34$ \\
$\mathrm{Cl}\left(\mathrm{mg} \mathrm{L}^{-1}\right)$ & $1.77 \pm 0.17$ & $2.05 \pm 0.25$ \\
$\mathrm{pH}$ & $6.76 \pm 0.04$ & $7.01 \pm 0.04$ \\
$\mathrm{Conductivity}\left(\mu \mathrm{S} \mathrm{cm}^{-1}\right)$ & $125 \pm 3.61$ & $287 \pm 3.18$ \\
$\mathrm{DO}$ & $5.66 \pm 0.54$ & $7.11 \pm 0.38$ \\
\hline
\end{tabular}

\section{Discussion}

The impact on vegetation structure was reflected by the differences in species composition between the rather pristine Madikane and impacted Dufuya sites. The species that were present in Madikane indicate a permanent or semi-permanent wetness (Phragmites australis, Ludwigia stolonifera, Cyperus articulatus, Carex cognata, Typha capensis, Epilobium salignum and Thelypteris confluens) (Everett, 1982a, 1982b) compared to species that require well-drained soils and can tolerate arid environments (Amaranthus hybridus, Cleome gynandra and Hypoestes forskalei), as in Dufuya. The dominance of species adapted to an arid environment especially in the outer region of Dufuya are indicative of the shrinking size of the dambo with increasing drought stress on the local biota. A continuous cultivation in Dufuya may therefore result in its disappearance.

The central regions of the two dambos were characterized by low species abundance but a different species composition. Competition with Phragmites australis and Cyperus articulatus in the centre of Madikane, Kyllinga erecta and Fimbristylis dichotoma in the centre of Dufuya could be strong and hence contribute to the low species diversity. These species tend to grow and colonize rapidly (Everett, 1982a, 1982b). The low species diversity in the central zones can also be attributed to high moisture content as few species are adapted to survive in areas where the soil is permanently waterlogged (Acres, 1985). Variation in competitive ability due to variation in soil characteristics is one possible mechanism allowing the local coexistence of plant species (Heather et al., 1997).

Dambo utilization resulted in a decrease of the indigenous species and facilitates the settlement of introduced and exotic species. Cleome gynandra and Amaranthus hybridus, indicator weeds for disturbance (Everett, 1982a) were only present in Dufuya. Fertilisation of natural ecosystems with phosphorous promotes common species at the expense of rare ones (Guseswell et al., 2005). 
The use of dambos can also change the vegetation growth form. This was shown by the presence of species indicating disturbance in Dufuya. Cynodon dactylon is a perennial species and an indicator for grazing. It has high cover abundance but no dominating effect because of its short growth form. C. dactylon had lower cover abundance in Dufuya compared to Madikane. Panicum repens, a species which grows in the transition zone between land and water is also preferred by herbivores (Skarpe, 1997). A shift of species composition from perennials to annuals due to dambo utilization was observed in Dufuya dambo. The annual species that dominated in Dufuya especially the outer regions were Eragrostis cylindriflora, Paspalum urvillei, Cleome gynandra, Amaranthus hybridus, Panicum repens and Bidens pilosa. In Madikane, there was a mixture of annual and perennials. The change in species composition through extinction is thought to alter the way solar energy is captured and the rate at which matter is cycled in an ecosystem (Chapin et al., 2000; Cardinale et al., 2002).

The levels of soil nitrogen were generally higher in Madikane than Dufuya. This is not an unusual feature in peat soils as it is explained by decomposition and mineralization of plant material which releases nitrogen back into the soil (Zedler, 2000). Fertilization of agricultural land led to an accumulation of phosphorus and nitrogen (Compton and Boone, 2000). The slightly higher level of phosphorus in Dufuya suggests the influence of external sources. The low levels of phosphorus in Madikane are also explained by uptake with rapidly growing dambo vegetation (Bruland et al., 2003) since flooded soils are associated with reducing conditions which increase the solubility and mobility of phosphorus (Zedler, 2000). A change in the levels of nitrogen and phosphorus may shift the composition of a plant community by promoting a rapid growth of species that are best adapted. Low nutrients and high base concentrations have been found to be responsible for higher plant diversity in wetlands (Wheeler and Shaw, 1995). Hence some of the observed differences in species composition may be explained by the differences in nutrient composition. Species richness was raised in wetlands through phosphorus fertilisation when the initial $\mathrm{N}$ : $\mathrm{P}$ ratio of vegetation was above 2.0 (Gusewell et al., 2005).

Agricultural activity in hydric soils does not always result in the depletion of soil organic carbon (Shaffer and Ernst, 1999). In our study, it was shown that the wetness of the soil, which was influenced by the position in the dambo, had an effect on total organic content (Figure 5) since organic carbon increased with an increase in moisture content. Few micro organisms that breakdown organic matter are adapted to live in relatively wet environments (Mclatchey and Reddy, 1988). The slight differences in organic carbon between Madikane and Dufuya may be attributed to cultivation since organic carbon is assumed to be $58 \%$ of total organic matter. Significant changes in soil physicochemical properties characterized by high bulk density and low organic matter were observed in meadows and pastures under utilisation (Kulik et al., 2007).

In Dufuya, the $\mathrm{pH}$ in water rapidly increased as the soil $\mathrm{pH}$ increased. This suggests a loss of $\mathrm{Ca}^{2+}$ and other cat-ions from the soil. Lime $\left(\mathrm{CaCO}_{3}\right)$ that is used to control soil $\mathrm{pH}$ act as a source of $\mathrm{Ca}^{2+}$. The effect of liming is also indicated by the small range of water $\mathrm{pH}$ in Dufuya than in Madikane. The increase of $\mathrm{Ca}^{2+}$ was also shown by a high conductivity of water in Dufuya than Madikane. There was a significant difference in the water quality between Madikane and Dufuya as evidenced by the differences in nutrient concentrations of phosphorus and nitrogen. The ability to improve water quality is often high in the presence of species like Phragmites australis and Typha capensis 
(Finalyson et al., 1986; Kadlec and Knight, 1996), which were more dominant in Madikane than in Dufuya. The high concentrations of total nitrogen recorded in water from both dambos (Table 4) are not an unusual feature as it is a characteristic of water from peat soils. The levels of nitrogen recorded in this study are close to those reported in Carolina and coastal wetlands (Bruland et al., 2003; Walbridge and Richardson, 1991).

Most of the nitrogen recorded in water could have been derived from peat soils through nitrification of ammonia produced from organic matter decomposition (Avinmelech et al., 1978) as evidenced by the high levels of nitrogen in the soil. The higher conductivity in Dufuya $\left(287 \mu \mathrm{S} \mathrm{cm}^{-1}\right)$ compared to Madikane $\left(125 \mu \mathrm{S} \mathrm{cm}^{-1}\right)$ is also explained by nutrient loading. Lime $\left(\mathrm{CaCO}_{3}\right)$ that is used to control soil $\mathrm{pH}$ act as a source of calcium. Leaching of calcium ions and other cations tend to increase the conductivity of water. A long term monitoring of the physical and chemical variables is needed so as to assess the extent of the impact of agriculture.

As dambo cultivation has to be fully recognized as an economic activity especially in the rural community, the question on dambo utilization is mainly how they should be used in a sustainable way. The current policy on dambo utilization has to be changed since it has allowed degradation to progress unchecked. Dambo farming under proper management emphasizing on community responsibility can result in sustainable use since dambos are a common property with no specific person responsible for their use or misuse. The management strategy has to be ecologically sound, economically viable, socially just, humane and adaptable.

Acknowledgements. This work was funded by the Government of Belgium through the University of Zimbabwe/Flemish Universities link (Aquatic Ecology Project). The assistance of Teresa Chitiga, Tsungayi Zengeya, Pamela Sibanda, Samuel Alferi and Taurai Bere who helped with fieldwork is gratefully acknowledged.

\section{REFERENCES}

[1] Acres, B.D. (1985): African dambos, their distribution, characteristics and use. Zeitschrift fur Geomorphologie, Supplementband 52: 63-86.

[2] Avinmelech, Y., Dasberg, S., Harpaz, A., Levin, I. (1978): Prevention of nitrate leakage from Hula basin, Israel: a case study in water management. - Soil Science 125: 233-239.

[3] Bennett, K.E. (1980): Keys to Zimbabwean grass species. - Kirkia 11(2): 169-286.

[4] Bray, R.H., Kurtz, L.T. (1945): Determination of total organic and available phosphorus in soils. - Soil Science 59: 39-45.

[5] Bruland, G.L., Hanchey, F.M., Richardson, J.C. (2003): Effects of agriculture and wetland restoration on hydrology, soils and water quality of a Carolina Bay complex. Wetlands Ecology and Management 11: 141-156.

[6] Cardinale, B.J., Palmer, M.A., Collins, S.L. (2002): Species diversity enhances ecosystem functioning via inter-specific facilitation. - Nature 415: 426-428.

[7] Chapin, F.S., Zareleta, E.S., Eviner, V.T., Naylor, R.L., Vitousek, P.M., Reynolds, H.C. (2000): Consequences of changing biodiversity. - Nature 404: 234-242.

[8] Chapano, C. (2002): A checklist of Zimabwean grasses. Southern African Botanical Diversity Network Report No. 16. - National Herbarium and Botanical Garden, Harare, Zimbabwe.

[9] Compton, J.E., Boone, R.D. (2000): Long term impacts of agriculture on soil carbon and nitrogen in New England forests. - Ecology 81: 2314-2330. 
[10] Dambo Research Unit (1987): The use of dambos in rural development with reference to Zimbabwe. Final report of ODA Project R3869. - Loughborough University: pp. 38-42.

[11] Djodjic, F., Bergstrom, L. (2005): Phosphorus losses from arable fields in Sweden effects of Field specific factors and long-term trends. - Environmental Monitoring and Assessment 102: 103-117.

[12] Djodjic, F., Bergstrom, L., Ulen, B., Shirmohammadi, A. (1999): Mode of transport of surface applied phosphorus-33 through a clay and sandy soil. - Journal of Environmental Quality 28: 1273-1382.

[13] Djodjic, F., Ulen, B., Bergstrom, L. (2000): Temporal and spatial variations of phosphorus losses and drainage in structured clay soil. - Water Research 34: 1687-1695.

[14] Everett, T. (1982a): The New York botanical garden illustrated encyclopedia of horticulture. Vol. 1. - Garland publishing Inc., New York, London.

[15] Everett, T. (1982b): The New York botanical garden illustrated encyclopedia of horticulture. Vol. 2. - Garland publishing Inc., New York, London.

[16] Everitt, B. (1993): Cluster analysis, $3^{\text {rd }}$ edn. - Arnold, London.

[17] Finalyson, C.M., Collen, P., Mitchell, D., Chuck, A. (1986): An assessment of a natural wetland receiving sewage effluent. - Austral Ecology 11: 33-47.

[18] Gee, G.W., Bouder, J.W. (1986): Particle size analysis. - In: Klute, A. (ed.) Methods of Soil Science Analysis Part I, pp. 383-409. Agronomy Monograhs 9, $2^{\text {nd }}$ edn. American Society of Agronomy, Madison, Wisconsin, USA.

[19] Gusewell, M., Roem, W.J., Bedford, B.L. (2005): Nutrient limitation and botanical diversity in wetlands: can fertilizers raise species richness? - Oikos 109: 71-80.

[20] Heather, R., Bruce, H, Carla, M. (1997): Soil heterogeneity and plant composition in annual grassland. - Ecology 78: 2076-2090.

[21] Kadlec, R.H., Knight, R.L. (1996): Treatment wetlands. - Lewis Publishers, Florida, USA.

[22] Keeney, D.R., Nelson, D.W. (1982): Nitrogen - inorganic forms. - In: Page A.L., Miller R.H., Keeney, D.R. (eds), Methods of Soil analysis Part II, Chemical and Microbiological Properties, Agronomy Monograhs 9, $2^{\text {nd }}$ edn. American Society of Agronomy, Madison, Wisconsin,USA.

[23] Kirsten, D. (2005): Economic consequences of wetland degradation for local people in Africa. - Ecological Economics 53: 177-190.

[24] Kulik, M., Bayla, R., Warda, M. (2007): The effect of grassland utilisation on physicochemical properties of peat-muck soils and species composition of sward. Agronomy Research 5: 147-154.

[25] Loreau, M. (2000): Biodiversity and Ecosystem function and recent theoretical advances. - Oikos 91: 3-17.

[26] Matiza, T. (1994): Wetlands in Zimbabwe: an Overview. - In: Matiza, T., Crafter, S.A. (eds) Wetlands Ecology and Priorities for Conservation in Zimbabwe. Proceedings of a Seminar on Wetlands Ecology and Priorities for Conservation in Zimbabwe. Kentucky Airport Hotel, Harare.

[27] McLatchey, G.P., Reddy, K.R. (1988): Regulation of organic matter decomposition and nutrient release in a wetland soil. - Journal of Environmental Quality 27: 1268-1274.

[28] Minitab (1995): Minitab Software Release 10.5 Extra. - Minitab Inc., State College, USA.

[29] Mitsch, W. J., Gosselink J.G. (1993): Wetlands. $2^{\text {nd }}$ Edn. - Van Nostrand Reinhold, New York.

[30] Naeem, S., Knops, J.M.H., Tilman, D., Howe, K.M., Kennedy, T., Gale, S. (2000): Plant diversity increases resistance to invasion in the absence of covarying factors. - Oikos 91: 97-108.

[31] Pimm, S.C., Russell, G.J. Gittleman, J.L., Brooks, T.M. (1995): The future of Biodiversity. - Science 269: 347-350. 
[32] Schnitzer, M. (1982): Total carbon, organic matter and carbon. - In: Page, A.L., Miller, R.H., Keeney, D.R. (eds) Methods of Soil analysis Part II, Chemical and Microbiological Properties. Agronomy Monograhs 9, $2^{\text {nd }}$ edn., American Society of Agronomy, Madison, Wisconsin, USA.

[33] Shaffer, P.W., Ernst, T.L. (1999): Distribution of soil organic matter in freshwater emergent/open water wetlands in the Port-land, Oregon metropolitan area. - Wetlands 19: 505-516.

[34] Shannon, C.E., Wienner, W. (1963): The Mathematical Theory of Communication. University of IIIinois, Urana, III, p.125.

[35] Skarpe, M. (1997): Ecology of the vegetation in the draw - down zone of Lake Kariba In: Moreau, J. (ed.) Advances in the ecology of lake kariba, UZ Publications, Harare, Zimbabwe.

[36] Sorensen, T. (1948): A method of establishing groups of equal amplitude in plant sociology based on similarity of species content. - Det. Kong. Danske Vidensk. Selsk BiologySkr (Copenhagen) 5: 1-34.

[37] Tilman, D. (1996): Biodiversity: Population versus ecosystem stability. Ecology 77: 350363.

[38] Vitousek, P.M., Mooney, H.A., Lubchneco, J. (1997): Human domination of the Earth's ecosystem. Science 277: 494-499.

[39] Walbridge, M.R., Richardson, C.J. (1991): Water quality of pocosins and associated wetlands of the coastal plain. - Wetlands 11: 417-438.

[40] Wheeler, R.D., Shaw, S.C. (1995): A focus on fens - Controls on the composition of fen vegetation in relation to restoration. - In: Wheeler, B.D., Shaw, S.C., Fojt, W.J., Robertson, R.A. (eds) Restoration of temperate wetlands. John Wiley, New York.

[41] Whitlow, J.R. (1983): Vlei cultivation in Zimbabwe - reflections on the past. Zimbabwe Agricultural Journal 80: 1234-135.

[42] Whitlow, J.R. (1984): A survey of dambos in Zimbabwe. - Zimbabwe Agricultural Journal 81: 129-138.

[43] Whitlow, J.R. (1985a): Research on dambos in Zimbabwe. - Zimbabwe Agricultural Journal 82: 29-66.

[44] Whitlow, J.R. (1985b): Dambos in Zimbabwe: a review. - Zeitschrift fur Geomorphologie, Supplementband 52: 115-146.

[45] Zedler, J.B. (2000): Restoration of biodiversity to coastal and inland wetlands. - In: Gopal, B., Junk, W.J., Davies, J.A. (eds) Biodiversity in wetlands: assessment, function and conservation. Vol. 1. Backhuys Publishers, Leiden. 